\title{
輻射熱の体䇥收支に及ぽす効果
}

\section{Thermal Balance to Heat Radiation}

\author{
慶忘義塾大学医学部衞生学公衆衞生学教室 \\ 含 田 正一 \\ Masakazu Kurata \\ Department of Preventive Medicine and Public Health, School of Medicine, Keio University
}

生体の内部環境の恒常性維持, ことでは体温の恒常性 維持を前提こして考える時, 代謝, 蒸発,輻射, 伝導, 対流 等の物理化学的諸因子が, 産熱放熱のため, 主こして気 温の変動に対して果す役割は，C. Winslow 等の Partitional Calorimetry ${ }^{1)}$ 以来急速な発展走した方法論 的分析の適用によつて，かなり事情が明らかになつてき ている。しかし一方, 外部温熱条件の変動は特殊な軦射 熱による場合がなかなか多い。これは産業職場に限らず 日常我々の家庭生活にも広く存在するのである。壁や天 井や床の輻射暖房 ${ }^{2}$ は別こしても，ストーブ類による採 暖法はまだ当分我々の身辺寺 去りそうもない。との場 合, 我从は着衣下で軽い仕事をしているのが普通であ る。従つて, 熱平衡維持のための産熱放熱に関する諸因 子の動きは, 裸体時と異なつて非常に複雑であろうこと は想像に難くない。体表面の温度孛考えてみても, 輻射 熱に直面する皮膚面または軽い衣服下皮膚面の温度上昇 は当然としても，輻射熱源に直面しない部位の皮膚温怡 熱平衡維持という生体の目的に向つてごのように動いて ゆくであろうか。衣服下皮虐部, 露出皮膚部によつても

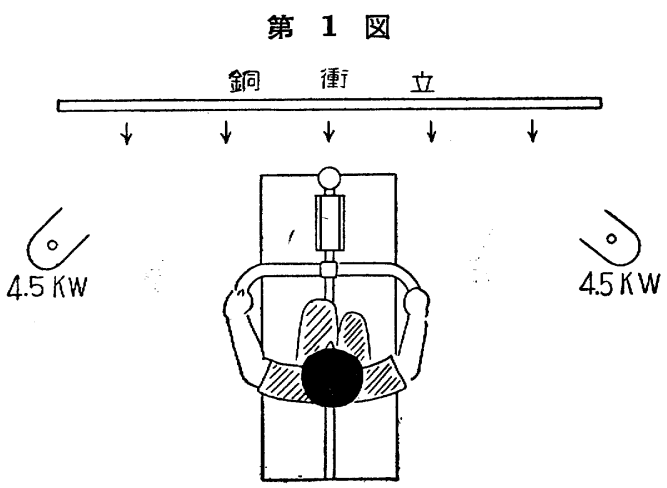

\begin{tabular}{|c|c|}
\hline 男子学生14名 & 自転車エルゴメーター \\
\hline 着 & $1 \mathrm{~kg}$ 負荷 \\
\hline 冬 $\longrightarrow$ 夏 & 100 回 $/$ 分 $2.2 \mathrm{~kg}$ 負荷 \\
\hline
\end{tabular}

その態度は異なるであろう。しかしての複雑な状態こそ 我くの日常遭遇している姿なのである。

元来, 外部温熱条件のうち輻射熱単独の生理的な効果 については記载が少なく，特に身体前面といつたある一 方向から輻射熱を受けた場合の熱平衡の様子社不明とい つてょい。最近著者は, 実験室で日常の衣服を着て軽い 作業字していて熱平衡状態にある被検者や裸体横臥時の 被検者の前面から一定の輻射熱孝負荷して(第1図), そ の際みられる産熱放熱に関する諸因子の動きを, 季節を 追つて測定した。実験成績の詳細については各々実験担 当者が別に記載するが314)，乙こでは熱平衡状態にある生 体に及ぼす輻射熱の一般的な効果について検討してみた い之思う。

\section{1. 身体熱平衡に関する諸因子計算の基礎}

衣服を着て軽い作業をてている生体が前面から輻射熱 を受けるといろ本実験のような場合に, 体温の恒常性維 持のために当然生体がこるべき産熱放熱に関する諸因子 の動きを考えてみよう。交ず生体の熱收支のうちでプン スに働く因子は，代謝による産熱（M) こ場合によつて は, 輻射 (R), 対流伝導 (C) による環境からの侵入熱 量であろろが, M以外はこの揚合複雑な関係にあるこ考 えられる。即ち, 直接照射学受けている部分からはRに よつて熱ぶ身体内に入つてくるであろうが，直接照射を 受けていない背面等の皮虐からは, 皮膚温や湿度にも占 ろろが，Rによつて熱が出てゅくし，全体表面とも多く の場合 Cによつて熱が出てゆくであろう。るた，直接輻 射熱尜受计ている皮膚面でも, 輻射源のもつ波長よりも つと長波の熱線が例えば床の表面との間で熱交換孛行了 であろう。いずれにしても，以上の $\mathrm{M}+\mathrm{R}+\mathrm{C}$ 熱収支の 考えろるプラス側ということになる。とれだけは生体に とつて何とかして放散しなければならない熱量となる。

これに対するマイナス側は， RやCも参加する場合は あろうが，乙の実験では大部分は蒸発（L）が主役を演 
ずるであろう。この蒸発による放熱量を律するものは, 皮膚粘膜上空気の物理的な蒸気圧の差並びに気流であつ て, 主として皮虐温, 気温がさらにてれを規定するてと になる。従つて蒸発によつて放散しうる最大熱量は, こ れらの因子によつて自ら決つてしまう。生体の発汗には 制限のあるととですあり，放散しなければならない熱量 がその時の「蒸発によつて放散しろる最大熱量」超過す ると平衡疷破れて遂には耐えがたいものとなつてくる。 著者の実験で注数例を除いて亦る状態法みられなかつ たが，産業高熱職場ではかかる状態がしばしば出現する わけである。なお, 放熱に関する上述の気温, 周囲物体

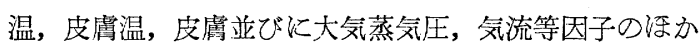
に, 放熱面積従つて姿勢や衣服が熱放散に大きな影響を もつてくることは当然である。

さて，以上の実験条件下の熱収支をいかなる方法でみ たらよいだろうか。John B. Pierce Laboratory of Hygiene で発展を示したょうに, 個別的に因子を計算 して求內たいところである。しかしての方法汸彼等も述 ベているょうに占，身体の一側からくる輻射や気流の影 響について触れておらず，彼等の導いた実験式を使用

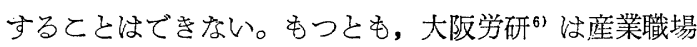
の熱環境の強さを, Winslow 等の熱平衡実験式を使用し て, 熱収支の総決算こしての熱貯藏量 Sの大きさでみて ゆくことを述べて輻射熱職場にも適用している。即ち， $\mathrm{M}-\mathrm{L} \pm \mathrm{R} \pm \mathrm{C}= \pm \mathrm{S}$ $\mathrm{M}, \mathrm{L}, \mathrm{R}, \mathrm{C}$ を計算して $\mathrm{S}$ を知 つて, $\mathrm{S}=0$ よりプラス側になつた時の $\mathrm{S}$ 大きさに意 味をもたせているのである。しかし著者就, 元来 $\mathrm{S} の$ 值 注三浦等の算出しているような $200 \mathrm{Cal} / \mathrm{m}^{2} / \mathrm{hr}$ こいつた 大きな值”がどうして生ずるのか疑問に思つている。試 みに体温が $1{ }^{\circ} \mathrm{C}$ 上昇した場合の $\mathrm{S}$ 計算してみると，体 重 $55 \mathrm{~kg}$ として, 身体の比熱を Du Bois に従つて0.83 とすれば約 $50 \mathrm{Cal} / \mathrm{m}^{2} / \mathrm{hr}$ となるにすぎず，代謝や蒸発 による熱量に比べると問題にならない。200 Cal という と直腸温が約 $4{ }^{\circ} \mathrm{C}$ 上昇するととになる。もつともとれ は，身体の熱党直腸温で代表させた場合であつて，全身 の皮下 $1 \mathrm{~cm}$ 位までの熱を皮膚温で代表させるとすれば 1/5（Du Bois）注皮膚温に帰せられるから直腸温として の上昇度は減少するであろろが, 冷却時と異なつて, 皮 膚温と直腸温の差はさ源ざ大きいと性考えられないか $ら^{121}$, 直腸温で代表させても大差なかろろ。また, 三浦㳊 $\mathrm{M}, \mathrm{L}, \mathrm{R}, \mathrm{C}$ 加減によつて計算した熱貯蔵量 $\mathrm{S}$ 加 体温上昇に要した熱量を差引くべきだと述べているが, それでは S は一体何なのか理解に苦しむ。 $\mathrm{M}, \mathrm{L}, \mathrm{R}, \mathrm{C}$ から計算された $\mathrm{S}$ が即ち体温上昇乞なつて現われてくる
のではないだろろか。それが直腸温で現わしうるかどう かはまた別問題である。むし，直腸温上昇から計算され る熱量と $\mathrm{M}, \mathrm{L}, \mathrm{R}, \mathrm{C}$ から計算された熱量が はなはだし く異なる場合は, 体温の代表として直腸温をとることが 不適当なをめか, あるい個別的にM, L, R, C学計算す るについて含宗れる多くの仮定の上に積久重衫られた愦 差 (計算の精度㤁ら当然予想される) をみているととに なるのではないだろろか。ただし, 直腸温の高さ注, 三 浦のいうょうに, 安静時学基準とするととはできない ことは勿論で, Berggren 等 ${ }^{81}$ は筋肉運動後 40〜50 分 で体温があるレ心゙ルに落着くと酸素消費量と体温々よく 相関するといつて抢り，気温についても同様であろう。 実験開始㹥この時期を選ぶべきであつて, 体温があるレ ベルに落着かないうちに早期に実験を始めて, 熱平衡式 から各因子を算出するととは適当と汸考方彶な。大 きな $\mathrm{S}$ 值はこの辺源因の一半があるのではなかろろ か。

こにかく,Winslow 自身が著者の試みんとする一面輻 射の影響については実験していないのであつて，彼の実 験式から各因子について個別的に特に輻射の効果だけを みるとと沦伦険であり，最近 Belding, Hatch 等の提 唱している Heat Stress Index ${ }^{9101}$ そしてもやはり同様 の関係にある。即ち， R, C雨因子彼等注次の式から 算出している。

$$
\begin{aligned}
& \mathrm{R}=22\left(\mathrm{t}_{\mathrm{w}}-95\right) \\
& \mathrm{C}=2 \sqrt{\mathrm{V}}\left(\mathrm{t}_{\mathrm{a}}-95\right)
\end{aligned}
$$

ここに壁温 $\left(\mathrm{t}_{\mathrm{w}}\right)$, 皮虙温, 気流 $(\mathrm{V})$, 気温 $\left(\mathrm{t}_{\mathrm{a}}\right)$ が 関係しているが，実験式の基礎となつている人体はいわ ゆる standard man であつて, 健康男子で体表面積 20

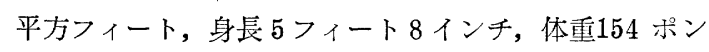
ドで裸体となつて抢り，平均皮虐温纯 $95^{\circ} \mathrm{F}$ と仮定して いる。熱負荷つ程度を指標化するに浪，このような標準 化は避けがたいし, Belding 汇兵士に適用してょかつた と著者に語つたが，少なくこも著者等の実験目的にはこ のょうにR，Cを個別的に扱うに梳ありに複雑であ る。例えば皮膚温は, 輻射值接曝される部位こ背中で は大差があろうし, 運動によつて熱分布状態も変つてく るであろう。気流にしても, 運動によつて生ずる相対的 な気流, 衣服亡体動による気流変化を考えると, 単なる 外部環境気流とはかなり異なつたものとなるであろう。

さて，輻射や対流の動き学個別的に求めることができ なければ, 残る方法注, 熱平衡式定基礎として测定可能 なものの值から算出するととである。即ち, 代謝による 産熱, 蒸発に上る放熱量の差兮ら輻射対流の効果定求め 
ることになる。幸い, E. Adolph は太隄直射下の砂漠熱 地行軍兵士について熱出納を調查していて ${ }^{11}$, 環境から の熱侵入として Environmental heat gain $(\mathbf{E})^{12}{ }^{12}$ 空用 いている。前述のように, 外部から体内に侵入してくる 熱 $(\mathrm{R}+\mathrm{C})$ と体内で産生される熱 (M) に対抗して熱 の平衡学維持してゆくための放熱因子は蒸発 (L) で ある。即ち,

$$
\mathrm{L}=\mathrm{M}+\mathrm{E} \pm \mathrm{S} \cdots(1)
$$

ここで Environmental heat gain (E) 㯰境から侵 入してくる熱の合計であつて, 勿論 $\mathrm{R} や \mathrm{C}$ がその中に含 まれる因子であつて, 著者等の実験の場合, 前述のょう に直接輻射熱に曝されている前面からは輻射にょる熱侵 入, 背面ては輻射による熱放散, 対流による熱放散等从 輻射対流によつて出入する熱の総決算として差引結局体 内へ侵入すると計算される熱量と考えてょい。乙の方法 によれば, $\mathrm{R} \mathrm{C}$ 個別的に計算する危険はなく, 誤差 も最小に止めることができるであるう。E. Adolph は (1) 式吕ら

$$
\mathrm{E}=\mathrm{L}-\mathrm{M} \pm \mathrm{S}
$$

彼注 $\mathbf{E}$ 熱環境の烈しさを現わす一つの指標として用 いている。著者はてのEを用いて, 前面からの輻射熱忍 実際に被険者に対して熱の侵入こなつて効いてくる時 即ち， $\mathrm{E}=0$ ( $\mathrm{L} \fallingdotseq \mathrm{M})$ として作用するとてろを知り, 前面輻射のない場合とごれほどの差があるかをみるとと にしたのである。

几注体重減少量に付着汗量の補正を加えててれに蒸発 潜熱 $0.56 \mathrm{Cal} / \mathrm{g}$ 学乗じて求め, $\mathrm{M}$ 注呼気分析から, S 汇 体重に比熱0.83(Du Bois) を乗じててれにさらに体温 変化を乗じて求めた。

\section{2. 輻射熱の体內侵入}

上述の $\mathrm{E}$ 算出するためには, まず $\mathrm{M}, \mathrm{L}, \mathrm{S}$ 㢳観察し なければならない。第 2 図は, 自転車エルゴメーター1 分間 80〜100 回転, 負荷 $1 \sim 2 \mathrm{~kg}$ の労作学課した時 の体内代謝による産熱量を, 輻射熱を与えない場合と比 較したものである。これによると，代謝愊射熱尗つ て上昇学示している。即ち, 同気温, 同作業下に拀い て, 輻射熱のない場合に比べて抢よそ16〜33\%の増加 定認めたのである。元来，代謝による産熱柱温熱因子亡 は独立していて主として筋肉活動によつて決つてくるも のである。しかし気温が非常に高い場合に注安静時酸素 消費量が高まることは一般比知られている ${ }^{1314}$ 14。本実験 では気温による代謝充進恃明らかでなが，輻射熱によ る充進仗明らかである。ただ， 4,5 月に測定したもの
第 2 図代謝と室温

自较車エルゴメーター 80 回/分 $1 \mathrm{~kg}$ 負荷

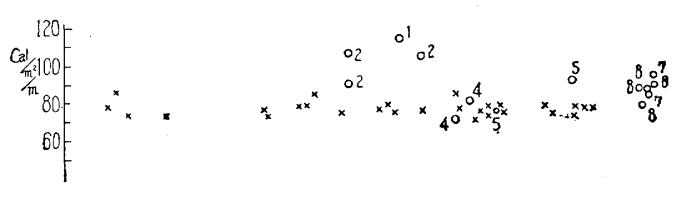

$\left(\begin{array}{c}\text { 輻射时 } \\ \text { 図中数字は測定月を輻射のない時 }\end{array}\right)$

自転車エルゴメーター 100 回/分 $2.2 \mathrm{~kg}$ 負荷

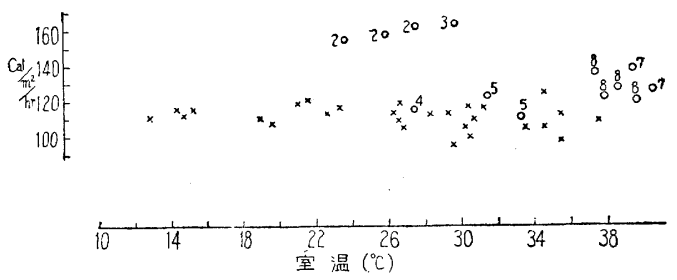

に輻射熱を負荷しない時と漂沽同值を示したものがあ る。これ壮測定が冬から夏にわたつたなめ現象を複雑に してしまつたさ考えら礼るのであつて,この 4 ，5月にみ る代謝元進の減弱快, かつて著者 ${ }^{15}$ が手背亦らの不感蒸 泄水分量を季節を追つて観察した際に，4，5，10月に異 常な低值を及たのこ何か関連があるように思われるので 西つて, 生体のもつ刺戟汶対する反応性化何季節的な 弾力性の差考感ずるのである。原島 ${ }^{16}$ は自律神経緊張度 定血液成分を通じて季節的に観察した場合，4月並びに 10月に交感神経, 副交感神経緊張の移行があるととを図 示しているし, 長屋 ${ }^{17} は$ 血清コリンェステラーゼ活性值 が季節的に 5，10月頃大きく方向变変えて夏型，冬型に 移行すると述べているので，ての 4,5 月の生理機能の 変動は特別な目でみてもよいのではないかと考えるので ある。

$\mathrm{S}$ 法, 熱平衡が体温のある高さで安定している状態に あつては，さ医ど大きな值をとるべきではないことは前 述した。実際,この実験では口腔温字通じてみた体温上昇 络室温 $38^{\circ} \mathrm{C}$ 以下では $0.2 \sim 0.4{ }^{\circ} \mathrm{C}$ の上昇を示すにすぎな 加たが，室温がこれ以上になると $1.0 \sim 2.0{ }^{\circ} \mathrm{C}$ の昇

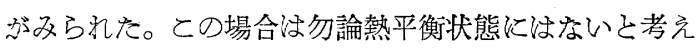
られる。これらの例を除けば，計算されたS经技よそ5 〜 $30 \mathrm{Cal} / \mathrm{m}^{2} / \mathrm{hr}$ にすぎなかつたのである。

L（有效な蒸発による放熱量）については, 気温上昇 に伴つて汗量が増加するととは当然であるが, 前面から の輻射熱つ負荷によつて同気温でもこの負荷のない時 に比べて汗量增加する。しかし，気温に対する発汗量 


\section{第 3 図 $E$ ，口腔温，㼣搏と室温（輻射のない時）}
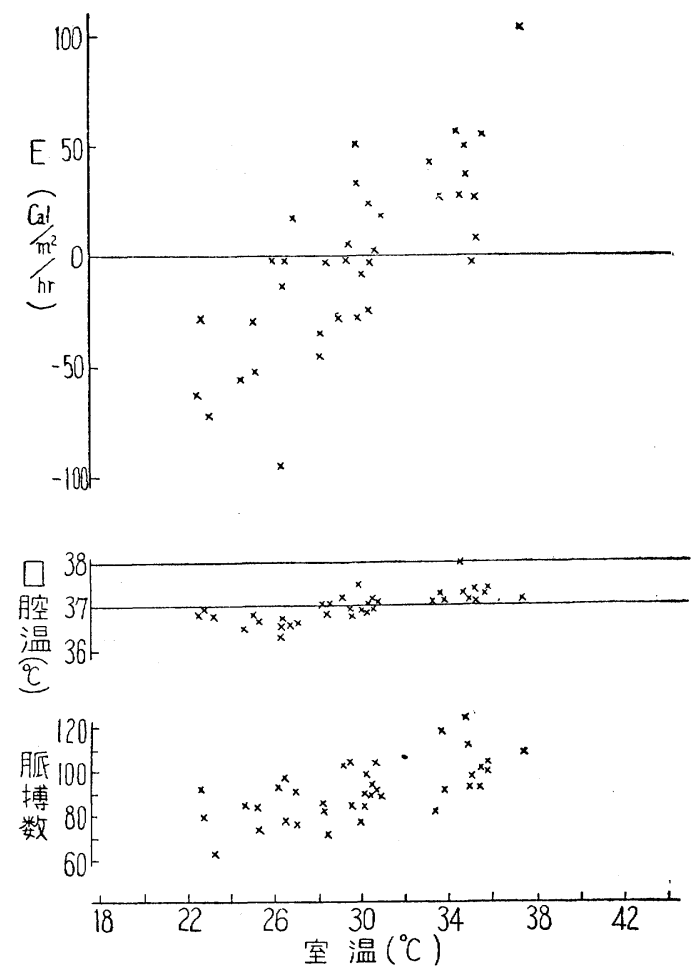

増加の率经輻射熱の負荷のない場合に比べて劣るょうで ある。発汗率に個人差のあるとと虫認められている ${ }^{18)} 。$ この場合にも相当な個人差を認めたが, 最大 $300 \mathrm{Cal} /$ $\mathrm{m}^{2} / \mathrm{hr}$ 超えるものはなかつた。

さて，以上のM， S， Lから目的の $\mathrm{E}$ 計算してみると 第 $3 ， 4$ 図のようになる。即ち， $\mathrm{E}=0$ 劣中心としてプ ラス側は生体への熱の侵入, 即ち輻射対流によつて生体 から放出される熱と，同じく輻射対流によつて侵入して く西熱定差引してみて結局体内への熱侵入となつて現わ れてくることを示している。両図とも相当各点は散つて いるが, 本図は気盜との関係のみについてみたものであ

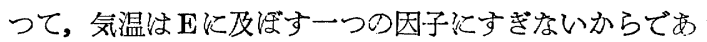
ろろし, 末た各点は 1 人 1 回の実験結果であつて, 被検 者 1 人について季節の影響を除いて短期間に観察を進め ればこれと注変つた形をとると考えられる。まず第 3 図 の輻射熱を負荷しない状態て観察すると， $\mathrm{E}=0$ のとと ろは, 著者の実験条件では, 気温扮よそ $30^{\circ} \mathrm{C}$ 付近にある ょうである。この気温ではまた, 口腔温が $37^{\circ} \mathrm{C}$ 台に入る 即5口腔温 $37^{\circ} \mathrm{C}$ 台で 熱平衡が 維持されて视く状態に入 つてゆく点でもあり, 脈搏もとの辺から増加の率を増し ているとと笏 3 図に示す通りである。一方，輻射熱を
第 4 図 E，口腔温，眽搏と室温〈輻射時〉
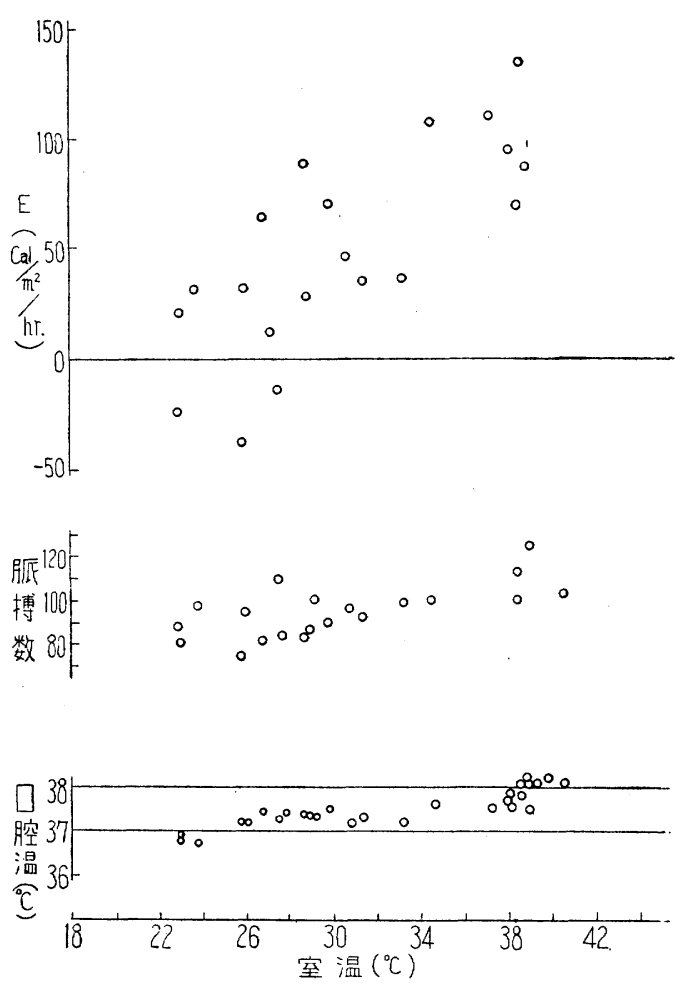

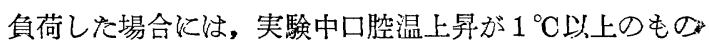
を除くと， $\mathrm{E}=0$ のところは少しく低気温側にずれて古 上そ $25^{\circ} \mathrm{C}$ 付近となつている。との気温 $25^{\circ} \mathrm{C}$ 付近亦ら体

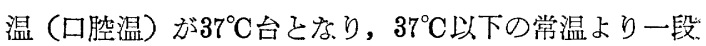
高いところで熱平衡が成立つてゆくことを示しており， また脈搏の増加率も大きくなるのであつて, $\mathrm{E}=0$ 办ら さらに熱の体内侵入への経過は口腔温や脈搏にとつて も一つの変化の推移点として関連导もつているとみら， れる。

著者はかつて夏季の紡績工場について女子織布精紡作 業者の身体熱出納学調べたととがある199。勿論との場合 の環境はいわゆる高温多湿であつて輻射熱㳇問題とする にたらぬ環境であつたが，しかし $\mathrm{E}=0$ は湿球温度 $27^{\circ} \mathrm{C}$ 付近にあつて, 口腔温や脈搏がこの温度付近から大きな 変化をみせをてと级本実験と全く一致するのであつて， 体内への熱侵入がとてから始まるとともに，一段と強力 な蒸発によつてての熱を捨ててゆくが, しかも次第によ り高い体温のもとで熱平衡が維持されてりくこ上を示し ているといえるのである。

ただ，実験時間 60 分のうちに $1{ }^{\circ} \mathrm{C}$ 以上体温が上昇す るというととは，まだ一定のレ心゙ルに体温が落着かぬ時: 
胁，あるい怔一定のレベルを保持できない 即ち熱平衡 が成立しえない状態と考えるべきで，かかる状態下で $\mathrm{E}$ を論ずることはできない。勿論 $\mathrm{M}+\mathrm{E}$ 放散するだけ充 分なLは，常に許されるものではないからであつて，前 述したように，理論的には $\mathrm{M}+\mathrm{E}>\mathrm{L}$ ，即ち放散さるべ き熱量がその時の蒸発によつて放散しろる熱量（皮虞と 空気の蒸気圧差, 気流, 蒸発有効面積等によつて律せ られる）を超過すれば熱平衡は破れ，体温の上暑度いか ん，即与身体に蓄積されてゅく熱いかんによつては耐え がたくなるわけである。本実験ですこのような数例に遭 遇したのであるが，いわゆる高熱環境の恕限度といつた 問題は $\mathrm{E}$ と蝣で，指標は自ら別のものについてみるべ きであり，ここでは全く触れない。

\section{3. 前面からの輻射熱と体表面温度}

熱負荷によつて皮膚への血液循環量の増加を, 従つて 皮膚の温度上昇をきたし，乙れによつて皮膚已環境の温 度差を增大し，蒸気圧を高めょうこすることは生体のも 顷であろう。

しかし，輻射熱を前面功与えた場合に心一般的熱負 荷にみられる体表面温度分布とは異なつた分布を示す㤌 ずである。直接照射された部位の皮温が上昇することは 当然であるが, その他の部位については, 前記エルゴメ ーター実験条件下では次のような結果を得た。室温 $20^{\circ} \mathrm{C}$ 付近では, 胸部背面の肩胛棘部皮温は運動開始後下降を 示して上昇がなかなか起らず，室温が $30^{\circ} \mathrm{C}$ 越すように なる己初めて下降から上昇に転ずる。下腿後面も同様な 順向にある。しかし室温がさらに高い場合，例えば室温 $40^{\circ} \mathrm{C}$ 付近でば測定点温度 (全身11個所 ${ }^{20)}$ ) は一齊に上昗 をみたのである。下腿後面の皮温下降柱, 自転車エルゴ メーターによる下腿運動の結果相対的に生ずる風速の冷 却効果 ${ }^{211}$ に主な原因があるのかもしれないが，背部の皮 温下降は特異な現象といかねない。運動を開始し て办ら 25 分後の肩胛棘部皮温法第 5 図に示すように，輻 射熱の負荷のない場合に比べて低下し，従つて気温との 差は小さくなるが, 室温 $30^{\circ} \mathrm{C}$ 辺でとの差がなくなつてい る。背面皮温下降現象については三浦 ${ }^{22}$ も裸体椅坐安静 時室温 $28^{\circ} \mathrm{C}$, 実効輻射温 $10^{\circ} \mathrm{C}$ 場合に認めているのであ つて, 発汗が主役定演ずるものであろろと述べている。さ て, 元来輻射熱に対する皮虞温の反応性には部位的な差 のあることが認められて招り，M. Bader'. $24^{\circ} \mathrm{C}$ 裸体時顔面を輻射熱加温した時手足で注 皮温上昇 を認めたが背中, 上腿, 上膊には変化が認められなかつた と記載している。また，著者が冬季裸体横卧時前面から

\section{第 5 図 輻射熱と肩㫓䊂部皮膚温}

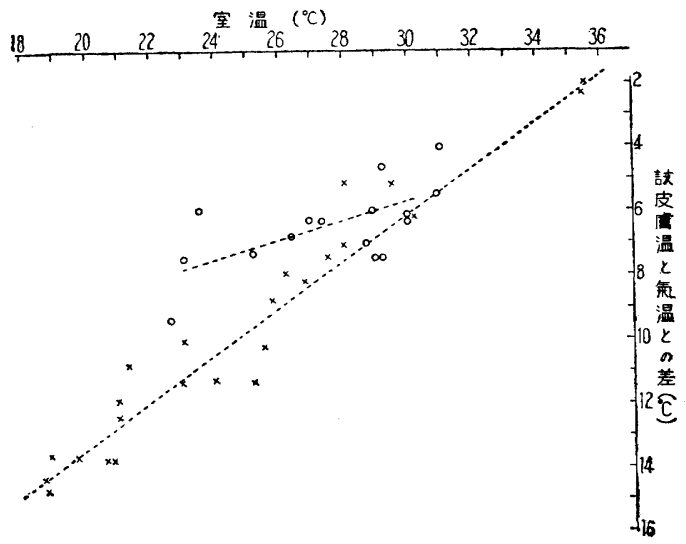

第6図皮清温分布

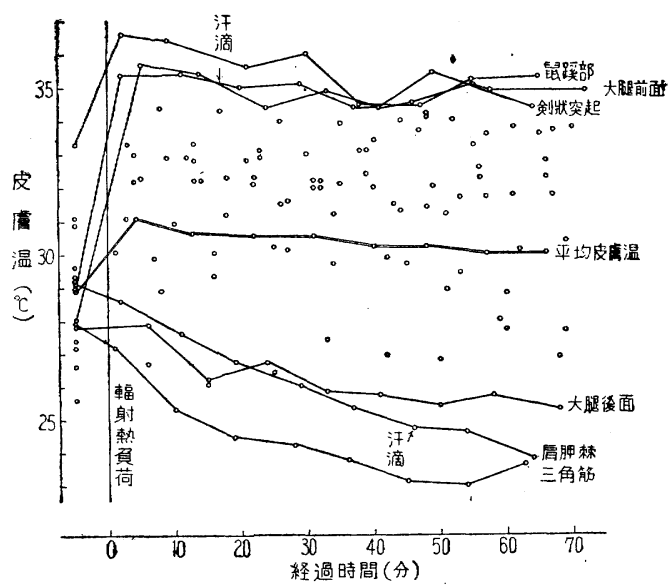

3 月 20 日 D.B.T. $19^{\circ} \mathrm{C} \quad \mathrm{T}_{\mathrm{G}} 37^{\circ} \mathrm{C}$ 23 歳学生 裸体横卧

輻射熱を与えて全身の皮温の消長を観察した結果“) は， 第 6 図のように背面皮温は物理的な冷却を思わせる直線 的な下降を示し, 輻射熱の影響が特に現われていない。 しかもこの間，ヨード溉粉による Minor 法で汗滴の出 現を調べると，胸部前面より少し遅れて横臥している生 体の上半身にまず出現するのである。とれらの事実から 考える己, やはり背面活手足のように熱負荷に対して敏 感に皮膚温にその変化党現わしえない部位已考えざるを えないのである。従つて第 5 図から類推されるょうに， 肩胛棘部皮温と氛温との差は，気温上昇に伴つて輻射熱 を負荷しない場合と一致して直線状に小さくなつてゆく であろろが，やがて発汗が輻射熱負荷のない場合より早 く強く起つてくるので，乙れによる鹪温が大きくなつて より早く気温との差度縮める。㬏射熱負荷のない場合に 
第 1 表 輻 射と体表面皘

23 歳今学生 身長 $166.8 \mathrm{~cm}$ 体重 $54.9 \mathrm{~kg}$

乾球温度 $17.0^{\circ} \mathrm{C}$

球 温度 $37.0^{\circ} \mathrm{C}$

\begin{tabular}{|c|c|c|c|c|c|c|c|c|c|}
\hline \multirow{2}{*}{\multicolumn{2}{|c|}{ 身体区分 }} & \multicolumn{2}{|c|}{ 全 体 表 面 } & \multicolumn{2}{|c|}{ 輻 射 } & \multicolumn{2}{|c|}{ 非 輻 射 面 } & \multicolumn{2}{|c|}{ 接 着 } \\
\hline & & $\%$ & $\mathrm{~cm}^{2}$ & $\%$ & $\mathrm{~cm}^{2}$ & $\%$ & $\mathrm{~cm}^{2}$ & $\%$ & $\mathrm{~cm}^{2}$ \\
\hline 頭 & 部 & 4.3 & 698 & 1.2 & 193 & 2.3 & 372 & 0.8 & 133 \\
\hline 顔、面 & 部 & 3.1 & 503 & 2.7 & 444 & 0 & 0 & 0.4 & 59 \\
\hline 䁰 & 部 & 2.4 & 390 & 0.5 & 82 & 1.2 & 197 & 0.7 & 111 \\
\hline 上 膊 & 部 & 8.2 & 1331 & 3.4 & 553 & 2.5 & 412 & 2.3 & 366 \\
\hline 前 膊 & 部 & 6.1 & 991 & 3.2 & 529 & 2.3 & 376 & 0.6 & 86 \\
\hline 手 & 部 & 5.3 & 861 & 2.5 & 419 & 2.5 & 400 & 0.3 & 42 \\
\hline 胸 & 部 & 16.6 & 2695 & 6.6 & 1064 & 8.4 & 1364 & 1.6 & 267 \\
\hline 腹 & 部 & 8.1 & 1315 & 3.0 & 481 & 2.8 & 456 & 2.3 & 378 \\
\hline 大 腿 & 部 & 25.3 & 4108 & 3.7 & 608 & 2.8 & 444 & 18.8 & 3056 \\
\hline 下 腿 & 部 & 13.4 & 2176 & 5.8 & 940 & 6.3 & 1021 & 1.3 & 215 \\
\hline 足 & 部 & 7.2 & 1169 & 2.3 & 362 & 4.4 & 726 & 0.5 & 81 \\
\hline 合 & 計 & 100.0 & 16237 & 34.9 & 5675 & 35.5 & 5768 & 29.6 & 4794 \\
\hline
\end{tabular}

は,ょり高気温においてやがててれを同じ現象が起つ て, 皮温乞気温との差は気温上昇に対してゅるや机な つてゅくのであろう。

なお, 前記裸体横臥実験で, 全身の平均皮膚温度を面

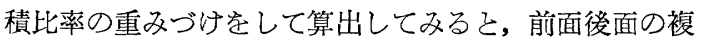
雑な皮温の動きにも拘らず，一定の気温下では浩济一定 した值を示したのである。即ち熱平衡状態が成立してい ることが示されたのである。A. Burton によると，才 ーストラリアの土民中には冬䈌寒にも拘らず裸体で焚火 を囲んで横臥する習慣があるこいうが24，乙のここは種 从な寒気馿化が成立つているとさは確かにしても，熱平 衡方ら考えると，焚火という輻射源六ら身体前面飞熱芑 取入れる反面に沙背面から放熱し，両者のバランスがそ れているととを物語つている。また，著者の実験例につ いて, 輻射受熱面積と輻射熱定直接受けていない面積之 が第 1 表のよ弓に拣济等しくなつており，皮膚と床との

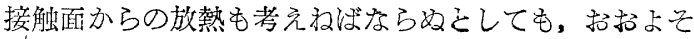
身体前面去ら取入れられた熱が蓄積し凉いように後面心 ら適度に放散されて両者の釣合がそれ熱平衡が維持され てゆくと考えられるのである。

$$
\text { 文献 }
$$

1) C. Winslow 他: Amer. J. Physiol., 120, 1 22, 1937.

2) F. Chrenko : Brit. J. Ind. Med., 14, 13 21, 1957.

3）田中竜男: 慶応医学, 34, 285 296, 昭32.
4) 倉田正一他: 日本衞生学雑誌, 揭載予定.

5) C. Winslow: Temperature and Human Life, P. 56, 1949.

6) 三浦武夫: 予防医学, 1, 115 123, 昭25.

7) 三浦武夫他: 労㗢科学季報, $1,1 \sim 8$, 昭28.

8) Berggren 他: Arbeitsphysiology, 14, 255 260, 1950.

9) H. Belding 他: Heating, Piping \& Air Conditioning, August, 129 136, 1955.

10) G. Haines 他: Reprint from Heating and Ventilating, Nov. 1952.

11) E. Adolph : Physiology of Man in the Desert, 1947.

12) E. Adolph : Amer. J. Physiol., 123, 486 499, 1938.

13）緒方維弘：交部省科学研究費関保季節生理班報 告書, 昭 28.

14）戸田嘉秋：国民衞生，23，1 7， 1954.

15）倉田正一：日新医学，37，343 350, 昭 25 .

16) 原島進: 日新医学, $40,574 \sim 580$, 昭 28 .

17) 長屋信美: 日新医学, $38,176 \sim 181$, 昭 26 .

18) D. Dill : Amer. J. Physiol., 123, 412 419, 1938.

19）蒼田正一他：労働科学，30，752 762, 昭 29 .

20）良田正一: 労働科学, $30,332 \sim 337$, 昭29.

21) A. Burton: J. Nut., 7, 481 496, 1934.

22) 三浦豊彥他: 労働科学, 32, 610 619, 昭31.

23) M. Bader : J. Appl. Physiol., 1, 215 226, 1948.

24) A. Burton: Man in the Cold Environment, 1955.

(受付: 1957年 7 月 23日) 